\title{
Minerals and Lactic Acid Contents in Buffalo Milk Cheddar Cheese; a Comparison with Cow
}

\author{
Mian Anjum Murtaza ${ }^{1, *}$, Nuzhat Huma ${ }^{2}$, Aysha Sameen ${ }^{2}$, Muhammad Saeed $^{2}$, Mian Shamas Murtaza $^{2}$ \\ ${ }^{1}$ Institute of Food Science and Nutrition, University of Sargodha, Sargodha, Pakistan \\ ${ }^{2}$ National Institute of Food Science and Technology, University of Agriculture, Faisalabad, Pakistan \\ *Corresponding author: anjum_ft@yahoo.com
}

Received July 23, 2014; Revised July 31, 2014; Accepted August 06, 2014

\begin{abstract}
The aim of the study was to compare the minerals and lactic acid profile of Cheddar cheese prepared from cow and buffalo milk. Milks standardized at $4 \%$ fat level were used to prepare Cheddar cheese. The cheese was prepared and stored for 120 days ripening at $4^{\circ} \mathrm{C}$. Chemical composition and minerals contents were determined at one month intervals during ripening. Lactic acid concentration was estimated after 2 and 4 months of ripening. The results revealed that cheese from buffalo milk had significantly higher level of fat, protein, ash, lactose and lactic acid contents as compared to that prepared from cow milk. Sodium, calcium and potassium contents were also considerably higher in the cheese prepared from buffalo milk. During ripening, significant decrease in lactose and $\mathrm{pH}$ value, while increase in acidity and lactic acid contents was observed. However, ripening did not influence the minerals profile of the cheese. It was accomplished that buffalo milk Cheddar cheese is nutritionally superior to cow milk cheese.
\end{abstract}

\section{Keywords: buffalo milk, cow milk, cheddar cheese, minerals, lactic acid}

Cite This Article: Mian Anjum Murtaza, Nuzhat Huma, Aysha Sameen, Muhammad Saeed, and Mian Shamas Murtaza, "Minerals and Lactic Acid Contents in Buffalo Milk Cheddar Cheese; a Comparison with Cow.” Journal of Food and Nutrition Research, vol. 2, no. 8 (2014): 465-468. doi: 10.12691/jfnr-2-8-6.

\section{Introduction}

Cheddar is a hard type of cheese having high nutritional value owing to the concentration of caseins which contain various levels of all essential amino acids, fat and small amounts of other nutrients like calcium, sodium, potassium, retinol, riboflavin, pyridoxine and cyanocobalamine [1]. Owing to higher concentration of nutrients, it is an important component of balanced diet [2].

Quality of Cheddar cheese depends upon starter cultures, manufacturing technology and composition of milk [3]. Milk composition is influenced by the animal type, individuality, health, feed, weather conditions and lactation stage of producing animal [4]. Cheese is a prepared from milk having dynamically balanced mixture of protein, fat, carbohydrates, vitamins, water, lactose, lactoglobulin, lactalbumin and water-soluble minerals [5].

Worldwide, Cheddar type cheese is produced from cow's milk, but buffalo's milk ranks second in production after cow. About $80 \%$ of the world's buffalo milk is produced in India and Pakistan and on account of its composition; it is much appropriate for soft and hard type of cheeses [2,6].

Buffalo’s milk is higher in fat, lactose, caseins, calcium, magnesium and inorganic phosphate than cow. Similarly, the capacity of milk to be acidified is better for buffalo's milk as compared to cow $[6,7]$. This milk is exceptional for production and manufacturing of various milk products owing to its nutritional composition and buffering capacity $[8,9]$.

During ripening, Cheddar cheese experiences momentous biochemical modifications and transformations because of glycolysis, proteolysis and lipolysis [1,10]. As a result, fresh curd having bland flavour and rubbery texture is converted into a product with attractive flavour and smooth texture [3,11]. The flavours produced in cheese are very multifaceted and comprise of substances including organic acids, which are the metabolites of bacterial cultures [2,12].

A primary function of bacterial culture is to convert the lactose into glucose or galactose, which are then converted into the end product of lactic acid. Lactic acid production is significantly influential on quality of cheese. In addition, the acidification contributes a preservative effect with the result that many pathogenic and spoilage bacteria are inhibited [13].

Lactic acid is the most plenteous organic acid present in cheese varieties. It is the metabolite of glycolysis reaction during cheese ripening [2,14]. Quantitative determination of lactic acid is important because it is an indicator of bacterial activity and contributes to cheese quality by imparting flavour $[15,16]$.

Keeping in view the above facts, the project was designed to compare the composition particularly the minerals and lactic acid contents in Cheddar cheese prepared from buffalo and cow milks. 


\section{Materials and Methods}

\subsection{Milk Samples}

Cow and buffalo milks were procured from University Farm House, Institute of Animal Nutrition and Feed Technology, University of Agriculture, Faisalabad, Pakistan. The milk samples were standardized at $4.0 \%$ fat level.

\subsection{Cheddar Cheese Manufacturing and Ripening}

Cheddar cheese samples were manufactured from cow and buffalo milk using direct in vat (DVS) Mesophilic starter cultures (Lactococcuslactisssp. cremorisand Lactococcuslactisssp. lactis) of CHR-Hansen, Denmark, following the standard protocol, with some modifications, as described by Murtazaet al [1].

\subsection{Cheese Ripening and Quality Evaluation}

Cheese samples were stored for ripening at $4^{\circ} \mathrm{C}$ for a period of 120 days. During ripening, samples were evaluated for various quality parameters.

\subsection{Composition}

Moisture, fat, protein, ash, $\mathrm{pH}$, acidity and salt (Volhard method) were determined following the protocols of AOAC [17] at one month intervals during ripening. Lactose contents were evaluated by Chloramine-T method as given by Kirk and Sawyer [18].

\subsection{Minerals Profile}

Minerals(sodium, potassium and calcium)contents in Cheddar cheese were determined using Flame Photometer following the method illustrated by Kirk and Sawyer [18] at the intervals of one month.

\subsection{Lactic Acid Contents}

Lactic acid concentration of cheese during ripening was determined after 2 and 4 months by High Performance Liquid Chromatography (HPLC) following the standard method given by Akalinet al [16].

A SHIMADZU liquid chromatograph (LC-10 AT VP Series, SHIMADZU Corporation, Japan) equipped with a SCL-10AVP system controller injector fitted with a $20 \mu \mathrm{l}$ sample loop and a SPD-10AVP UV-VIS detector was used. The detector's wavelength was set at $214 \mathrm{~nm}$.

\subsection{Statistical Analysis}

Results drawn from the study were statistically analysed using Completely Randomized Design (CRD) and Analysis of Variance (ANOVA) Technique to compare the chemical composition, lactic acid and mineral contents of Cheddar cheese from cow and buffalo milks [19].

\section{Results and Discussion}

\subsection{Composition}

The compositional analysis of Cheddar cheese (Table 1) showed that cheese prepared from buffalo milk had significantly $(\mathrm{p}<0.01)$ lower moisture $(35.76 \pm 0.24 \%)$ and higher fat $(31.77 \pm 0.09 \%)$, protein $(26.41 \pm 0.11 \%)$, ash $(4.07 \pm 0.006 \%)$ and lactose $(0.12 \pm 0.004 \%)$ contents as compared to cow milk. However, salt content, $\mathrm{pH}$ value and acidity were non-significantly $(\mathrm{p}>0.05)$ influenced by the milk sources.

Table 1. Chemical composition and minerals profile of cow and buffalo milk Cheddar cheese

\begin{tabular}{|c|c|c|}
\hline Ripening days & Cow & Buffalo \\
\hline Moisture (\%) & $36.74 \pm 0.23 \mathrm{a}$ & $35.76 \pm 0.24 \mathrm{~b}$ \\
Fat (\%) & $30.23 \pm 0.096 \mathrm{~b}$ & $31.77 \pm 0.091 \mathrm{a}$ \\
Protein (\%) & $25.22 \pm 0.03 \mathrm{~b}$ & $26.41 \pm 0.11 \mathrm{a}$ \\
Ash (\%) & $3.84 \pm 0.009 \mathrm{~b}$ & $4.07 \pm 0.006 \mathrm{a}$ \\
pH value & $5.26 \pm 0.012$ & $5.26 \pm 0.018$ \\
Acidity (\%) & $0.93 \pm 0.005$ & $0.93 \pm 0.005$ \\
Sodium (mg/100g) & $667.55 \pm 0.84 \mathrm{~b}$ & $682.68 \pm 0.60 \mathrm{a}$ \\
Calcium (mg/100g) & $723.68 \pm 1.10 \mathrm{~b}$ & $755.00 \pm 1.23 \mathrm{a}$ \\
Potassium (mg/100g) & $83.07 \pm 0.49 \mathrm{~b}$ & $86.43 \pm 0.48 \mathrm{a}$ \\
\hline
\end{tabular}

Different letters in columns indicate significantly different values at $\mathrm{p} \leq$ 0.05

The considerable variation in composition of cheese prepared from two different species are because the buffalo milk is richer in milk constituents especially fat, lactose and caseins $[6,8]$ and these significant inter-species differences are reflected in the characteristics of the cheeses produced [20].

During ripening of 120 days (Table 2 and Table 3), moisture, fat, protein, ash and salt contents changed nonsignificantly $(\mathrm{p}>0.05)$. However, lactose decreased significantly $(\mathrm{p}<0.01)$ from $0.15 \pm 0.005$ to $0.06 \pm 0.004 \%$ resulting in significant drop of $\mathrm{pH}$ and increase in acidity from $5.34 \pm 0.021$ to $5.19 \pm 0.024$ and $0.90 \pm 0.007$ to $0.96 \pm 0.006 \%$, respectively.

Table 2. Effect of ripening on moisture, fat, proteinand ash contents of Cheddar cheese

\begin{tabular}{|c|c|c|c|}
\hline Ripening days & Moisture (\%) & Fat (\%) & Protein (\%) \\
\hline 0 & $36.99 \pm 0.39$ & $31.32 \pm 0.22$ & $26.05 \pm 0.18$ \\
60 & $36.66 \pm 0.36$ & $31.18 \pm 0.21$ & $26.01 \pm 0.18$ \\
90 & $36.21 \pm 0.36$ & $30.99 \pm 0.22$ & $25.80 \pm 0.15$ \\
120 & $35.78 \pm 0.40$ & $30.81 \pm 0.21$ & $25.68 \pm 0.19$ \\
\end{tabular}

Table 3. Effect of ripening on salt, lactose, $\mathrm{pH}$ and acidityof Cheddar cheese

\begin{tabular}{|c|c|c|c|}
\hline Ripening days & Salt (\%) & Lactose (\%) & pH \\
\hline 0 & $1.60 \pm 0.012$ & $0.15 \pm 0.005 \mathrm{a}$ & $5.34 \pm 0.021 \mathrm{a}$ \\
60 & $1.62 \pm 0.007$ & $0.12 \pm 0.005 \mathrm{~b}$ & $5.28 \pm 0.023 \mathrm{~b}$ \\
90 & $1.62 \pm 0.007$ & $0.10 \pm 0.006 \mathrm{c}$ & $0.90 \pm 0.007 \mathrm{e}$ \\
120 & $1.63 \pm 0.009$ & $0.08 \pm 0.005 \mathrm{~d}$ & $0.93 \pm 0.006 \mathrm{bc}$ \\
$0.025 \pm 0.022 \mathrm{bc}$ & $5.23 \pm 0.023 \mathrm{c}$ \\
\hline
\end{tabular}


The fermentation of lactose resulted in fall of $\mathrm{pH}$ and rise in acidity because various metabolic reactions and transformations including glycolysis occur during cheese ripening $[1,10]$. Among these reactions, the conversion of lactose into lactate and other metabolic products by lactic acid producing bacteria is imperative and manipulate the concentration and production rate of acidification [20]. Onget al [21]also reported that during ripening, the lasting lactose content predominantly converted and transformed into L-lactate and ultimately the lactic acid.

\subsection{Minerals Profile}

Minerals analysis of Cheddar cheese (Table 4) revealed that cheese prepared from buffalo milk contained significantly $(\mathrm{p}<0.01)$ higher sodium $(682.68 \pm 0.60$ $\mathrm{mg} / 100 \mathrm{~g})$, calcium $(755.00 \pm 1.23 \mathrm{mg} / 100 \mathrm{~g})$ and potassium $(86.43 \pm 0.48 \mathrm{mg} / 100 \mathrm{~g})$ as compared to cow with mean values of $667.55 \pm 0.84 \mathrm{mg} / 100 \mathrm{~g}, 723.68 \pm 1.10$ $\mathrm{mg} / 100 \mathrm{~g}$ and $83.07 \pm 0.49 \mathrm{mg} / 100 \mathrm{~g}$, respectively. The significant differences in minerals profile of cheese are found because as compared to cow, buffalo milk contains considerably higher minerals contents especially calcium $[7,8]$.

Table 4. Effect of ripening on minerals profileof Cheddar cheese

\begin{tabular}{|c|c|c|c|}
\hline Ripening days & Sodium $(\mathrm{mg} / 100 \mathrm{~g})$ & Calcium $(\mathrm{mg} / 100 \mathrm{~g})$ & Potassium $(\mathrm{mg} / 100 \mathrm{~g})$ \\
\hline 0 & $671.17 \pm 2.25$ & $736.17 \pm 3.66$ & $80.67 \pm 0.62$ \\
30 & $673.25 \pm 1.82$ & $736.96 \pm 3.61$ & $82.29 \pm 0.69$ \\
60 & $675.38 \pm 1.67$ & $738.58 \pm 3.69$ & $85.33 \pm 0.65$ \\
90 & $677.00 \pm 1.81$ & $741.71 \pm 3.82$ & $87.08 \pm 0.52$ \\
120 & $678.79 \pm 1.82$ & $743.29 \pm 3.81$ & $88.38 \pm 0.50$ \\
\hline
\end{tabular}

Minerals contents increased non-significantly ( $>00.05)$ during ripening. The slight increase might be result of non-significant decrease in moisture content during 120 days. Since minerals are not engaged in any microbiological, biochemical or metabolic process occurring during ripening thus minerals contents are influenced non-significantly [22].

\subsection{Lactic Acid}

The concentration of lactic acid produced in Cheddar cheese during ripening showed that buffalo milk cheese contained significantly higher lactic acid than cow (Figure 1). The considerable difference between cow and buffalo milk cheeses may be due to the significant differences in the composition of both types of milk as the milk from buffalo is more affluent in casein, lactose and fat contents than cow $[7,8]$ and moreover, along with these differences, the capacity of milk to be acidified is higher for buffalo than cow $[2,6]$.

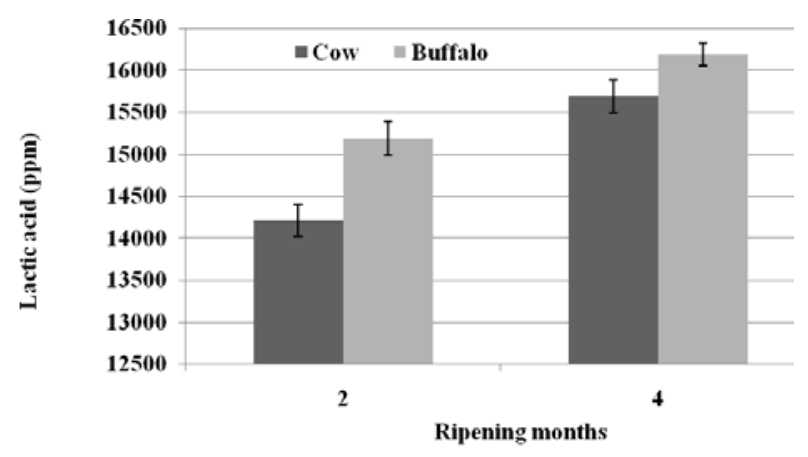

Figure 1. Lactic acid contents of cow and buffalo milk Cheddar cheese

After 4 months of cheese ripening, significant increase in lactic acid concentration was observed as compared to 2 months (Figure 1). This increase may be due to the metabolic transformations of remaining lactose and related compounds during ripening. At the start of ripening, lactose is quickly metabolized into lactate. This lactate is an imperative precursor for the production of lactic acid through a series of metabolic reactions and transformations including microbial processes, oxidationreduction reactions and racemisation [10,23]. Murtazaet al [2] also found the increase in lactic acid concentration in
Cheddar cheese during the first few weeks of ripening owing to the use of residual lactose trapped in the curd.

\section{Conclusion}

Hence, it was concluded that buffalo milk cheese is nutritionally superior to cow as it contains better compositional profile especially the minerals and lactic acid contents. Moreover, during ripening the concentration of lactic acid increased significantly, while minerals profile was influenced non-significantly.

\section{References}

[1] Murtaza, M. A.-Rehman, S. U.-Anjum, F. M.-Huma, N.-Hafiz, I.: Cheddar Cheese Ripening and Flavor Characterization: A Review. Critical Reviews in Food Science and Nutrition, 54, 2014, pp. 1309-1321.

[2] Murtaza, M. A.-Rehman, S. U.-Anjum, F. M.-Huma, N.-Tarar, O. M.-Mueen-ud-Din, G.: Organic acids contents of buffalo milk Cheddar cheese as influenced by accelerated ripening and sodium salt. Journal of Food Biochemistry, 36, 2012, pp. 99-106.

[3] Murtaza, M. A.-Rehman, S. U.-Anjum, F. M.-Huma, N.: Descriptive sensory profile of cow and buffalo milk Cheddar cheese prepared using indigenous cultures. Journal of Dairy Science, 96, 2013a, pp. 1380-1386.

[4] Fox, P.F.-Guinee, T. P.-Cogan, T. M.-McSweeney, P. L. H.: Fundamentals of Cheese Science. Aspen publishers Inc., Gaithersburg, Maryland. 2000.

[5] Jabbar, K.-Huma, N.-Bajwa, U. A.-Ehsan, B.-Khurram, A.: Preparation and Evaluation of Gouda Cheese with Different Fat Levels from Buffalo Milk. International Journal of Agriculture and Biology, 5, 2003, pp. 662-664.

[6] Ahmad, S.-Gaucher, I.-Rousseau, F.-Beaucher, E.-Piot, M.Grongnet, J. F.-Gaucheron, F.: Effects of acidification on physicochemical characteristics of buffalo milk: A comparison with cow's milk. Food Chemistry, 106, 2008, pp. 11-17.

[7] Fundora, O.-Gonzalez, M. E.-Lezcano, O.-Montejo, A.-Pompa, N.-Enriquez, A. V.: A comparative study of milk composition and stability of Murrah river buffaloes and Holstein cows grazing star grass. Cuban Journal of Agricultural Science, 35, 2001, pp. 219222.

[8] Murtaza, M. A.-Rehman, S. U.-Anjum, F. M.-Nawaz, H.: Nutritional comparison of cow and buffalo milk Cheddar cheese. Pakistan Journal of Nutrition, 7, 2008, pp. 509-512.

[9] Murtaza, M.A.-Grandison, A. S.-Huma, N.-Ahmad, S.-Murtaza, M. S.: Microstructure, rheological and textural characteristics of low fat buffalo milk Cheddar cheese. Buffalo Bulletin, 32 (Special Issue 2), 2013b, pp. 1346-1351. 
[10] Farkye, N.Y.: Cheese technology. International Journal of Dairy Technology, 57, 2004, pp. 91-98.

[11] Smit, G.-Smit, B. A.-Wim, J. M.-Engels, J. M.: Flavour formation by lactic acid bacteria and biochemical flavour profiling of cheese products. FEMS Microbiology Reviews, 29, 2005, pp. 591-610.

[12] Banks, J.M.: Cheddar-Type Cheese. Hannah Research Institute, Ayr, Elsevier, Science Publication, UK. 2002.

[13] Sameen, A.-Anjum, F. M.-Huma, N.-Khan, M. I.: Comparison of locally isolated culture from yoghurt (Dahi) with commercial culture for the production of mozzarella cheese. International Journal of Agriculture and Biology, 12, 2010, pp. 231-236.

[14] Azarnia, S.-Robert, N.-Lee, B.: Biotechnological methods to accelerate Cheddar cheese ripening. Critical Reviews in Biotechnology, 26, 2006, pp. 121-143.

[15] Califano, A.N.-Bevilacqua, A. E.: Multivariate analysis of the organic acids content of Gouda type cheese during ripening. Journal of Food Composition and Analysis, 13, 2000, pp. 949-960.

[16] Akalin, A.S.-Gonc, S.-Akbas, Y.: Variation in organic acids content during ripening of pickled white cheese. Journal of Dairy Science, 85, 2002, pp. 1670-1676.
[17] AOAC: Official methods of analysis of AOAC international $18^{\text {th }}$ Ed., AOAC International, 481 North Frederick Avenue, Gaithersburg, Maryland, USA, 2005.

[18] Kirk, S.R.-Sawyer, R.: Pearson's Composition Analysis of Food. AWL, Harlow, England, UK. 1991.

[19] Steel, R. G. D.-Torrie, J. H.-Dickey, D. A.: Principles and Procedures of Statistics. A Bio-Metrical Approach $3^{\text {rd }}$ Ed. New York, USA: McGraw Hill Book Co., Inc., 1997.

[20] Fox, P.F.-McSweeney, P. L. H.: Cheese: an overview, In: Fox, P.F.-McSweeney, P. L. H.-Cogan, T. M.-Guinee, T. P. (Eds.): Cheese Chemistry, Physics and Microbiology; General Aspects, Vol. 1, $3^{\text {rd }}$ Ed. Academic Press, London, UK. 2004.

[21] Ong, L.-Henriksson, A.-Shah, N. P.: Proteolytic pattern and organic acid profiles of probiotic Cheddar cheese as influenced by probiotic strains of Lactobacillus acidophilus, Lb. paracasei, $L b$. caseior Bifidobacteriumsp. International Dairy Journal, 17, 2007, pp. 67-78.

[22] Singh, T.K.-Drake, M. A.-Cadwallader, K. R.: Flavor of cheddar cheese: A chemical and sensory perspective. Comprehensive Reviews in Food Science and Food Safety, 2, 2003, pp. 139-162.

[23] McSweeney, P.L.H.: Biochemistry of cheese ripening. International Journal of Dairy Technology, 57, 2004, pp. 127-144. 